\title{
Food preparation methods among older adults at Qena city: impact of nutritional educational intervention
}

Nadia Omar Emam Abdelnasser ${ }^{1 *}$, Hoda Diab Fahmy ${ }^{2}$, Mohamed Kamal Alsayed $^{3}$, Asmaa Kamal Hassan², HuiJun Chih ${ }^{4}$

${ }^{1}$ Department of Gerontological Nursing, South Valley University, Egypt.

${ }^{2}$ Department of Community Health Nursing, Faculty of Nursing, Assuit University, Egypt.

${ }^{3}$ Department of Food Science \& Technology, Faculty of Agriculture, Assiut University, Egypt.

${ }^{4}$ Department of Epidemiology and Biostatistics, School of Public Health, Curtin University, Australia.

* Correspondence: E-mail: drnadia.abdelnaser@ nurs.svu.edu.eg

Postal address: South Valley University, Faculty of Nursing, Department of Gerontological Nursing, Qena, 83523, Egypt

\section{Abstract}

Background: The common preparation methods of usual food types in Egypt are boiling, grilling, frying, or raw and the most used one is frying method. So, It is an inevitable to improve older adults' nutritional habits especially the food preparation method. Aim: this study aimed to improve older adults' nutritional habits in form of food preparation methods. Method: The study followed a quasi-experimental research design. This study was conducted in the elderly club at Qena city, Egypt. A convenient sample of 106 older adults from total hundred fifty (150) members of the elderly club who fulfilled the inclusions criteria was randomly assigned to experimental or control group. The experimental group received the health education program and the control group didn't receive the health education program. Results: Within the intervention group, the preparation method has been significantly changed from frying to boiling or grilling most of food after telling the participants that the healthy method is boiling and /grilling. Conclusion: The results of the study confirm that there were improvements of older adults' nutritional habits in form of food preparation methods.

Keywords : food preparation method, older adults, nutritional habits, nutritional education

\begin{tabular}{|l|l|l|}
\hline Receive Date : 25/11/2020 & Accept Date: 28/11/2020 & Publish Date : 1/12/2020 \\
\hline
\end{tabular}

\section{Introduction}

There is increasing evidence that good nutrition is an important lifestyle factor essential to the health, independence and quality of life of older adults and one of the major determinants of successful aging $(1,2,3)$.

Meeting the need for optimal nutritional status for older people living at home requires knowledge of individual preferences and habits, from both their earlier and current lives. Individual needs for self-determination and involvement should be considered in planning and development efforts for elderly people related to food and meals (4).

As people get older, there are many age-related factors that influence their health, including decreased appetite, limited food intake, altered gut absorption of nutrients, and use of multiple medications that may 
lead to chronic disorders. Therefore, older adults present a unique set of nutrition challenges, as they may be deficient in some essential nutrients including protein, vitamins, and minerals, although they are not aware of these deficiencies as well as the food preparation method. Nutrition education therefore is critical to support health, reduce the risk and delay the onset of chronic diseases in this population $\mathbf{( 5 , 6 )}$. It is an attractive, non-invasive means of enhancing and optimizing important physiological functions among elderly people $\mathbf{( 7 , 8 )}$.

Although, researchers proved that effectiveness of nutritional educational intervention in Egypt and recommended that diet therapy programs need to be a priority on management of elderly $(\mathbf{9 , 1 0 , 1 1 )}$, there is a lack of nutrition education intervention among elderly in Egypt thus, the aim of this study is improving older adults' nutritional habits in form of food preparation methods.

\section{SUBJECTS AND METHOD}

This study aimed generally to improve older adults' nutritional habits in form of food preparation methods.

\section{Research design}

The study followed a quasi-experimental research design.

\section{Research hypotheses}

Community dwelling older adults who received the proposed study intervention exhibit healthier food preparation methods after the implementation of the study program than those who do not receive it.

\section{Setting:}

The study was conducted in the elderly club named “Nady Elmosneen", the only elderly club at Qena city, Egypt. This club service the elderly people from all cities of Qena governorate and provide medical and recreational services.

\section{Sample:}

A convenient sample of 106 older adults from total hundred fifty (150) members of the elderly club who fulfilled the inclusions criteria was randomly assigned to experimental or control group. The experimental group received the health education program and the control group didn't receive the health education program. Hundred and six (106) elderly persons from both sex, their age started from sixty years and free from any mental diseases according to their score of Mini-Mental State Examination scale (he/she must obtain 24-30 score) participated in the study. They were randomly assigned equally to two groups (Intervention group and control group) by write down each older adult's name using a 
piece of paper and collect these papers in a container then take fifty-three pieces of papers to be the intervention group and the others been the control group.

\section{Tools of the study: (Measurements)}

Two tools were used in this study to collect the necessary data as follows:

\section{Tool I: Mini-Mental State Examination scale (MMSE) (appendix I).}

The MMSE was developed by Folstein et al, 1975 and consists of 11 simple questions or tasks grouped into 5 cognitive domains (12) which are orientation, registration of three words, attention \&calculation, recall of three words and language. A possible score of 30 is used to provide a picture of an individual's present cognitive performance based on direct observation of completion of test items/tasks.

A score which less than 24 is the generally an accepted cutoff indicating the presence of cognitive impairment. Levels of impairment have been classified as the following:

○ No impairment: score $=24-30$

○ Mild impairment: score $=18-24$

- Severe impairment: score $=0-17$

\section{Tool II: Structured interview form:}

This tool was developed by the researcher based on relevant literature to asses sociodemographic characteristic and nutritional habits. Also, tool validity was tested for content by five nursing and medical experts in the related fields and it was valid. The reliability was measured by Cronbach's Alpha and it was reliable 0.90 . It consists of two parts.

\section{Part one: Socio-demographic structured interview form:}

This part contains a set of questions concerning socio-demographic data as age, sex, and level of education.

\section{Part two: Dietary intake structured} interview:

This part assesses nutritional habits in form of food preparation method, food preferences from previous 24 hours.

\section{Intervention (Health Education Program)}

\section{Control group:}

All subjects answered all tools questions as a baseline, and late post-test after three months. The researcher measured glucose level and blood pressure as a motivation services to encourage subjects to complete participation.

\section{Intervention group:}

All subjects received the same knowledge about the healthy preparation methods of food through two sessions. The researcher used prepared booklet, brochure, and poster to clarify the information. Also, blood glucose level and blood pressure were 
measured each session to encourage subjects to attend.

\section{Statistical analysis}

Data were collected on paper documents, uploaded to Microsoft Excel for storage, and transferred to STATA, version 12, for analysis. Nominal variables, such as gender, marital status, and educational level, were described using frequency counts and are presented as $\mathrm{n}(\%)$. Chi-square $\left(x^{2}\right)$ test or fisher exact test was used to test associations between nominal variables.

\section{Results}

Table (1) shows the Sociodemographic characteristics of the intervention and the control group. All subjects in both group were categorized into two categories: aged from sixty to sixty four and from sixty five to above. While the demographics of the two groups are not identical, there are no significant association observed $(\mathrm{p}>0.05)$.

Table (1): Sociodemographic characteristics of the intervention and the control group.

\begin{tabular}{|c|c|c|c|c|c|c|}
\hline \multirow[t]{2}{*}{$\begin{array}{l}\text { Sociodemographic } \\
\text { characteristics }\end{array}$} & \multicolumn{2}{|c|}{$\begin{array}{l}\text { Intervention } \\
\text { Group } \\
(\mathbf{n}=\mathbf{5 0})\end{array}$} & \multicolumn{2}{|c|}{$\begin{array}{l}\text { Control Group } \\
\qquad(n=53)\end{array}$} & \multirow[t]{2}{*}{$X^{2}$} & \multirow[t]{2}{*}{ P-value * } \\
\hline & $\mathbf{N}$ & $\%$ & $\mathbf{N}$ & $\%$ & & \\
\hline \multicolumn{7}{|l|}{ Age: } \\
\hline From 60 to 64 & 27 & 54.0 & 23 & 43.4 & \multirow[t]{2}{*}{1.1581} & \multirow[t]{2}{*}{0.282} \\
\hline from 65 and above & 23 & 46.0 & 30 & 56.6 & & \\
\hline \multicolumn{7}{|l|}{ Sex: } \\
\hline Male & 28 & 56.0 & 23 & 43.4 & \multirow[t]{2}{*}{1.6350} & \multirow[t]{2}{*}{0.201} \\
\hline Female & 22 & 44.0 & 30 & 56.6 & & \\
\hline \multicolumn{7}{|l|}{ Marital status: } \\
\hline Married & 40 & 80.0 & 37 & 69.8 & \multirow[t]{2}{*}{1.4153} & \multirow[t]{2}{*}{0.234} \\
\hline Widowed & 10 & 20.0 & 16 & 30.2 & & \\
\hline \multicolumn{7}{|l|}{ Educational level: } \\
\hline Illiterate & 15 & 30.0 & 19 & 35.9 & \multirow{3}{*}{5.6811} & \multirow{3}{*}{0.058} \\
\hline $\begin{array}{l}\text { Less than secondary (includes } \\
\text { Able to read \&write at primary } \\
\text { level)". }\end{array}$ & 10 & 20.0 & 19 & 35.9 & & \\
\hline Secondary and high & 25 & 50.0 & 15 & 28.3 & & \\
\hline
\end{tabular}

* Significant at $\leq 0.05$ as reported from fisher exact test 
Table (2) reflects the list of food which consumed cooked and raw. All study subjects within intervention and control group reported that they consumed protein sources as (meat, poultry, fishes, eggs,

Table (2) : The most common food consumption in Egypt and its preparation methods as reported by all study subjects within the intervention and control group.

\begin{tabular}{|c|c|}
\hline \multicolumn{2}{|c|}{ Food consumption and its preparation methods $(n=106)$} \\
\hline Food consumed cooked & Food consumed raw \\
\hline 1. Red meat & 1. Milk \\
\hline 2. Fatty meat & 2. Yoghurt \\
\hline 3. Canned meat & 3. Cheese \\
\hline 4. Non-fatty poultry (Chicken, rabbit) & 4. Raw Vegetables \\
\hline 5. Fatty poultry (Duck, pigeon) & 5. Fruits \\
\hline 6. Fresh fishes & 6. White bread \\
\hline 7. Frozen fishes & 7. Whole bread \\
\hline 8. Legumes \&beans & 8. Jam, honey, molasses \\
\hline 9. Eggs & 9. Beverages \\
\hline 10. Cooked Vegetables & \\
\hline 11. Rice / pasta & \\
\hline 12. Potato, sweet potato, taro & \\
\hline
\end{tabular}

Table 3A illustrates the comparison of protein sources preparation method (boiling or frying) between pre-test and late post-test within intervention and control group. It is interesting to notice that most of intervention subjects at pre-test had fried their food such as red meat, fatty meat, non-fatty poultry, and fatty poultry $(66.7 \%, 78.3 \%, 70.0 \%$, 75.0 respectively) while at late post-test,
Legumes \&beans) and carbohydrate sources as (rice/pasta, and Potato, sweet potato, taro) cooked. While they consumed fruits, cheese, bread, jam, honey, and molasses raw. 
Table (3A): Comparison of protein sources preparation method between pre-test and late post-test within the intervention and control group.

\begin{tabular}{|c|c|c|c|c|c|c|c|}
\hline \multirow[b]{2}{*}{ Food } & \multirow[b]{2}{*}{$\begin{array}{l}\text { Preparation } \\
\text { method }\end{array}$} & \multicolumn{3}{|c|}{ Intervention group } & \multicolumn{3}{|c|}{ Control group } \\
\hline & & $\begin{array}{c}\text { Pre } \\
\text { N } \\
(\%)\end{array}$ & $\begin{array}{c}\text { late post- } \\
\text { test } \\
\mathbf{N} \\
(\%)\end{array}$ & $\begin{array}{c}\text { p- } \\
\text { value* }\end{array}$ & $\begin{array}{c}\text { Pre } \\
\mathbf{N} \\
(\%)\end{array}$ & $\begin{array}{c}\text { late post- } \\
\text { test } \\
\mathbf{N} \\
(\%)\end{array}$ & $\underset{*}{\text { p-value }}$ \\
\hline \multirow[t]{2}{*}{ Red meat } & Boiled/grilled & $\begin{array}{c}11 \\
(33.3) \\
\end{array}$ & $\begin{array}{c}29 \\
(76.3) \\
\end{array}$ & \multirow[t]{2}{*}{$0.001 *$} & $\begin{array}{c}7 \\
(18.9) \\
\end{array}$ & $\begin{array}{c}12 \\
(31.6)\end{array}$ & \multirow[t]{2}{*}{0.289} \\
\hline & Fried & $\begin{array}{c}22 \\
(66.7) \\
\end{array}$ & $\begin{array}{c}9 \\
(23.7) \\
\end{array}$ & & $\begin{array}{c}30 \\
(81.1) \\
\end{array}$ & $\begin{array}{c}26 \\
(68.4) \\
\end{array}$ & \\
\hline \multirow[t]{2}{*}{ Fatty meat } & Boiled/grilled & $\begin{array}{c}5 \\
(21.7)\end{array}$ & $\begin{array}{c}13 \\
(68.4)\end{array}$ & \multirow[t]{2}{*}{$0.004^{*}$} & $\begin{array}{c}4 \\
(19.1)\end{array}$ & $\begin{array}{c}5 \\
(25)\end{array}$ & \multirow[t]{2}{*}{0.719} \\
\hline & Fried & $\begin{array}{c}18 \\
(78.3) \\
\end{array}$ & $\begin{array}{c}6 \\
(31.6) \\
\end{array}$ & & $\begin{array}{c}17 \\
(81) \\
\end{array}$ & $\begin{array}{c}15 \\
(75) \\
\end{array}$ & \\
\hline \multirow[t]{2}{*}{$\overline{\text { Canned meat }}$} & Boiled/grilled & $\begin{array}{c}0 \\
(0.0)\end{array}$ & $\begin{array}{c}3 \\
(30)\end{array}$ & \multirow[t]{2}{*}{0.070} & $\begin{array}{c}1 \\
(20)\end{array}$ & $\begin{array}{c}2 \\
(40)\end{array}$ & \multirow[t]{2}{*}{1.000} \\
\hline & Fried & $\begin{array}{c}7 \\
(100)\end{array}$ & $\begin{array}{c}3 \\
(50)\end{array}$ & & $\begin{array}{c}4 \\
(80)\end{array}$ & $\begin{array}{c}3 \\
(60)\end{array}$ & \\
\hline \multirow{2}{*}{$\begin{array}{l}\text { Non-fatty } \\
\text { poultry } \\
\text { (Chicken } \\
\text { rabbit) }\end{array}$} & Boiled/grilled & $\begin{array}{c}15 \\
(30)\end{array}$ & $\begin{array}{c}34 \\
(68.0)\end{array}$ & \multirow[t]{2}{*}{$0.001^{*}$} & $\begin{array}{c}10 \\
(18.9)\end{array}$ & $\begin{array}{c}15 \\
(28.3)\end{array}$ & \multirow[t]{2}{*}{0.360} \\
\hline & Fried & $\begin{array}{c}35 \\
(70.0) \\
\end{array}$ & $\begin{array}{c}16 \\
(32.0)\end{array}$ & & $\begin{array}{c}43 \\
(81.1) \\
\end{array}$ & $\begin{array}{c}38 \\
(71.7) \\
\end{array}$ & \\
\hline \multirow{2}{*}{$\begin{array}{l}\text { Fatty poultry } \\
\text { (Duck, } \\
\text { pigeon) }\end{array}$} & Boiled/grilled & $\begin{array}{c}8 \\
(25)\end{array}$ & $\begin{array}{c}22 \\
(68.8)\end{array}$ & \multirow[t]{2}{*}{$0.001^{*}$} & $\begin{array}{c}5 \\
(19.2)\end{array}$ & $\begin{array}{c}7 \\
(28)\end{array}$ & \multirow[t]{2}{*}{0.523} \\
\hline & Fried & $\begin{array}{c}24 \\
(75.0)\end{array}$ & $\begin{array}{c}10 \\
(31.3) \\
\end{array}$ & & $\begin{array}{c}21 \\
(80.8) \\
\end{array}$ & $\begin{array}{c}18 \\
(72)\end{array}$ & \\
\hline \multirow[t]{2}{*}{ Fresh fishes } & Boiled/grilled & $\begin{array}{c}0 \\
(0.0)\end{array}$ & $\begin{array}{c}20 \\
(40)\end{array}$ & \multirow[t]{2}{*}{$0.001^{*}$} & $\begin{array}{c}1 \\
(1.9)\end{array}$ & $\begin{array}{c}7 \\
(13.5)\end{array}$ & \multirow[t]{2}{*}{0.060} \\
\hline & Fried & $\begin{array}{c}50 \\
(100)\end{array}$ & $\begin{array}{c}30 \\
(60)\end{array}$ & & $\begin{array}{c}51 \\
(98.1)\end{array}$ & $\begin{array}{c}45 \\
(86.5) \\
\end{array}$ & \\
\hline \multirow[t]{2}{*}{ Frozen fishes } & Boiled/grilled & $\begin{array}{c}0 \\
(0.0)\end{array}$ & $\begin{array}{c}1 \\
(25)\end{array}$ & \multirow[t]{2}{*}{0.444} & $\begin{array}{c}0 \\
(0.0)\end{array}$ & $\begin{array}{c}2 \\
(28.6)\end{array}$ & \multirow[t]{2}{*}{0.462} \\
\hline & Fried & $\begin{array}{c}5 \\
(100) \\
\end{array}$ & $\begin{array}{c}3 \\
(75) \\
\end{array}$ & & $\begin{array}{c}7 \\
(100)\end{array}$ & $\begin{array}{c}5 \\
(71.4) \\
\end{array}$ & \\
\hline \multirow[t]{2}{*}{$\overline{~ E g g s}$} & Boiled/grilled & $\begin{array}{c}21 \\
(53.9)\end{array}$ & $\begin{array}{c}23 \\
(59)\end{array}$ & \multirow[t]{2}{*}{0.820} & $\begin{array}{c}20 \\
(50)\end{array}$ & $\begin{array}{c}21 \\
(53.9)\end{array}$ & \multirow[t]{2}{*}{0.823} \\
\hline & Fried & $\begin{array}{c}18 \\
(46.2)\end{array}$ & $\begin{array}{c}16 \\
(41)\end{array}$ & & $\begin{array}{c}20 \\
(50)\end{array}$ & $\begin{array}{c}18 \\
(64.2)\end{array}$ & \\
\hline
\end{tabular}

* Significant at $\leq 0.05$ as reported from fisher exact test.

Table (3B) illustrates the comparison of carbohydrates sources preparation method (boiling or frying) between pre-test and late post-test within intervention and control group. It is interesting to notice that only one of intervention subjects at pre-test had boiled his/her cooked vegetable and the number increase to nineteen at late post-test with highly statistical significance $(\mathrm{P}=0.001)$. Also, the number of intervention subjects who boiled rice or pasta was zero at pre-test 
and become seven at late post-test with statistical significance $(\mathrm{P}$ value $=0.012)$. Compared to control group, there is no statistical significance between preparation method at pre-test and late post-test $(\mathrm{P}>$ $0.05)$.

Table (3B): Comparison of carbohydrates sources preparation method between pre-test and late post-test within intervention and control group.

\begin{tabular}{|c|c|c|c|c|c|c|c|}
\hline \multirow[t]{2}{*}{ Food } & \multirow{2}{*}{$\begin{array}{l}\text { Preparation } \\
\text { method }\end{array}$} & \multicolumn{3}{|c|}{ Intervention group $\mathbf{N}(\%)$} & \multicolumn{3}{|c|}{ Control group N (\%) } \\
\hline & & Pre & $\begin{array}{l}\text { Follow } \\
\text { up }\end{array}$ & $\begin{array}{l}\text { p- } \\
\text { values* }\end{array}$ & Pre & $\begin{array}{c}\text { Follow } \\
\text { up }\end{array}$ & p-values* \\
\hline \multirow{2}{*}{$\begin{array}{l}\text { Legumes } \\
\text { \&beans }\end{array}$} & $\begin{array}{l}\begin{array}{l}\text { Boiled } \\
\text { grilled }\end{array} \\
\end{array}$ & $\begin{array}{c}49 \\
(100) \\
\end{array}$ & $\begin{array}{c}49 \\
(100) \\
\end{array}$ & \multirow[t]{2}{*}{------- } & $\begin{array}{c}53 \\
(100) \\
\end{array}$ & $\begin{array}{c}53 \\
(100) \\
\end{array}$ & \multirow[t]{2}{*}{------- } \\
\hline & Fried & $\begin{array}{c}0 \\
(0.0) \\
\end{array}$ & $\begin{array}{c}0 \\
(0.0) \\
\end{array}$ & & $\begin{array}{c}0 \\
(0.0) \\
\end{array}$ & $\begin{array}{c}0 \\
(0.0) \\
\end{array}$ & \\
\hline \multirow[t]{2}{*}{$\begin{array}{l}\text { Cooked } \\
\text { Vegetable }\end{array}$} & $\begin{array}{l}\text { Boiled } \\
\text { grilled }\end{array}$ & $\begin{array}{c}1 \\
(2)\end{array}$ & $\begin{array}{c}19 \\
(38)\end{array}$ & \multirow[b]{2}{*}{$0.001 *$} & $\begin{array}{c}1 \\
(1.9)\end{array}$ & $\begin{array}{c}2 \\
(3.8)\end{array}$ & \multirow[t]{2}{*}{1.000} \\
\hline & Fried & $\begin{array}{c}49 \\
(98) \\
\end{array}$ & $\begin{array}{c}31 \\
(62) \\
\end{array}$ & & $\begin{array}{c}52 \\
(98.1) \\
\end{array}$ & $\begin{array}{c}51 \\
(96.2) \\
\end{array}$ & \\
\hline \multirow[t]{2}{*}{ Rice / pasta } & $\begin{array}{l}\text { Boiled } \\
\text { grilled }\end{array}$ & $\begin{array}{c}0 \\
(0.0)\end{array}$ & $\begin{array}{c}7 \\
(14.3)\end{array}$ & \multirow[b]{2}{*}{$0.012 *$} & $\begin{array}{c}1 \\
(1.9)\end{array}$ & $\begin{array}{c}2 \\
(3.8)\end{array}$ & \multirow[t]{2}{*}{1.000} \\
\hline & Fried & $\begin{array}{c}49 \\
(100) \\
\end{array}$ & $\begin{array}{c}42 \\
(85.7) \\
\end{array}$ & & $\begin{array}{c}52 \\
(98.1) \\
\end{array}$ & $\begin{array}{c}51 \\
(96.2) \\
\end{array}$ & \\
\hline \multirow[t]{2}{*}{$\begin{array}{l}\text { Potato, sweet } \\
\text { potato, taro }\end{array}$} & $\begin{array}{l}\text { Boiled } \\
\text { grilled }\end{array}$ & $\begin{array}{c}14 \\
(35.9)\end{array}$ & $\begin{array}{c}19 \\
(48.7)\end{array}$ & \multirow[t]{2}{*}{0.359} & $\begin{array}{c}10 \\
(20)\end{array}$ & $\begin{array}{c}11 \\
(22)\end{array}$ & \multirow[t]{2}{*}{1.000} \\
\hline & Fried & $\begin{array}{c}25 \\
(64.1)\end{array}$ & $\begin{array}{c}20 \\
(51.3)\end{array}$ & & $\begin{array}{c}40 \\
(80)\end{array}$ & $\begin{array}{c}39 \\
(78)\end{array}$ & \\
\hline
\end{tabular}

* Significant at $\leq 0.05$ as reported from fisher exact test.

\section{Discussion}

The purpose of this study is to improve older adults' nutritional habits in form of food preparation methods by design, implement and evaluate the health education program. Sociodemographic characteristics of the intervention and control group were quiet similar. One hundred and six (106) participants were randomly assigned to 53 as a control group and 53 as intervention group (Table 1). Only three intervention participants dropped out during implementation of the program and 50 participant were interestingly completing all the program sessions.

The sessions were being run smoothly at the wide, good ventilated, and enough lighted hall in the elderly club twice a week at $6 \mathrm{pm}$. Booklet, brochures, and posters were used to clarify the information. They were designed to suit the older adults' abilities and capabilities using large bold font, colours with high contrast to be easy to older adults to see and read such as red, yellow, and orange and avoid using low contrast colours which is difficult for older 
adults to see and read such as green, blue, and purple. The researcher intended to highlight the most important parts. All previous materials contain more images but the brochure specifically contains more images with true and false signs to be suitable to illiterate participants. To increase the interaction in program sessions, the researcher provided opportunities for participants to ask questions and to discuss their information.

According to our study results, nutrition educational intervention is effective for change the unhealthy nutritional habits to $\checkmark$ healthy habits in terms of preparation methods. These results are in consistent with Muchiri et al, in South Africa who confirmed that Nutrition education improved specific dietary behaviours (13) and Kim B. et al, who concluded that the total dietary behaviour score of elderly increased from 28.1 to 31.2 after the education program $(\mathrm{P}<$ 0.001) (14).

The usual food types consumed in Egypt are beef, poultry, fishes, beans and legumes, available vegetables and fruits are obtained in Egypt each in its own growing season, some in winter, other in summer such as orange, watermelon, grape, pear, mango, capsicum, green beans, peas, tomato, spinach) bread (white, whole), rice, pasta, potatoes, jam, molasses, and beverages such as tea, fruits juice.
The common preparation methods of usual food types in Egypt are boiling, grilling, frying, or as it is and the most used one is frying method. Within the intervention group, the preparation method has been significantly changed from frying to boiling or grilling most of food (Table 3A, 3B) after telling the participants that the healthy method is boiling and / grilling the food while the unhealthy method is frying which provide body with unwanted fats and carcinogens. At post-test, this study reflects that the number of participant who do boiling or grilling of food such as red meat, fatty meat, canned meat, and fatty poultry increased while the number of participant who do frying of food decreased. Also, there is no significant change of consuming as it is (Table 3A, 3B).

These observation are in agreement with changes in specific dietary habits before and after participation in nutrition educationbased cooking workshops $(\mathrm{p}<0.05)$ offered in Southern Quebec by Moreau et al, to determine if nutrition education-based cooking workshops helped improve dietary habits among participants aged 50 years and older $(n=144)$ in an 8-session cooking workshop program (15). Similar results were obtained by Flego et al, in Australia who evaluated the immediate and sustained effectiveness of the first Jamie's Ministry of Food Program in Australia on individuals' 
cooking confidence and positive cooking/eating behaviours. Statistically significant increases at immediately post program were sustained at 6 months post program in the intervention group. Jamie's Ministry of Food Program, Australia improved individuals' cooking confidence and cooking/eating behaviours contributing to a healthier diet and is a promising community-based strategy to influence diet quality (16).

In contrast Wrieden et al, in Eight urban communities in Scotland, UK done the intervention named "Cookwell" to increase cooking confidence and food preparation methods. There were no significant differences (p-value $>0.05)$ in the proportions reporting that they assembled meals from ready-made ingredients (e.g. pasta and ready-made sauce), used convenience foods or added salt during cooking in either comparison or intervention participants across the three time points (17).

\section{Conclusion}

The results confirm that there were improvements of older adults' nutritional habits in form of food preparation methods.

\section{Declaration}

\section{Consent for publication N/A}

Availability of data and materials

The datasets used and analyzed during the current study are available from the corresponding author on reasonable request.

\section{Competing interests}

The authors declare that they have no competing interests.

\section{Funding}

This research did not receive any specific grant from funding agencies in the public, commercial, or not-for-profit sectors.

\section{Acknowledgements}

The authors acknowledge all elderly participants of the study.

\section{References}

1- Leslie, W. and Catherine, H. "Aging, Nutritional Status and Health." Healthcare (Basel, Switzerland) 2015, 3(3): $\quad$ 648-58. doi:10.3390/healthcare3030648

2- Power, S E. et al. "Food and nutrient intake of Irish community-dwelling elderly subjects: who is at nutritional risk?." The journal of nutrition, health \& aging 2014, 18(6): 561-72. doi:10.1007/s12603-014-0449-9

3- Suominen, M H. et al. "Nutritional guidelines for older people in Finland." The journal of nutrition, health \& aging 2014, 18(10): 861-7. doi:10.1007/s12603-014-0509-1

4- Edfors, A \& Westergren, A: HomeLiving Elderly People's Views on Food and Meals. Journal of Aging Research 2012, 1-9. doi:10.1155/2012/761291

5- Krondl M., et al: "Helping Older Adults Meet Nutritional Challenges." Journal of Nutrition For the Elderly 2008, 27(34): 205-220. 
6- Wunderlich Sh., et al: "Measuring the Impact of Nutrition Education and Physical Activity on Older Adults Participating in Government Sponsored Programs." Journal of Nutrition For the Elderly 2009, 28(3): 255-271.

7- Shahar, S. et al. "Development and Analysis of Acceptance of a Nutrition Education Package among a Rural Elderly Population: An Action Research Study." BMC geriatrics 2012, 12(1): 24.

8- Rea, J. et al. "How Effective Is Nutrition Education Aiming to Prevent or Treat Malnutrition in Community-Dwelling Older Adults? A Systematic Review." European geriatric medicine 2019, 10(3): 339-358.

9- Hegazy, I. S., et al: "Study of the effect of dietary counselling on the improvement of end-stage renal disease patients." Eastern Mediterranean Health Journal 2013, 19(1): 45-51.

10-Abd Allah, E., et al: "Effect of Diet Therapy Program on Dietary Knowledge and Practice of Elderly Patients on Regular Hemodialysis." American Journal of Nursing Science 2015, 4(3): 131-137.

11-El-sol, A., et al: "Effect of Educational Nursing Intervention About Osteoporosis on Adult's Knowledge." American Journal of Nursing Science 2016, 5(6): 272-279

12-Folstein M. and Folstein S: "MiniMental State" a Practical Method for Grading the Cognitive State of Patients for the Clinician." Journal of Psychiatric Research 1975, 12(3): 189198
13-Muchiri, J. W., et al: "Effect of a nutrition education programme on clinical status and dietary behaviours of adults with type 2 diabetes in a resource-limited setting in South Africa: a randomised controlled trial." Public Health Nutrition 2016, 19 (1): 142-155.

14-Kim, B., et al: "The effect of a nutritional education program on the nutritional status of elderly patients in a long-term care hospital in Jeollanamdo province: health behavior, dietary behavior, nutrition risk level and nutrient intake." Nutr Res Pract. 2012, 6(1): 35-44.

15-Moreau, M., et al: "Efficacy of Nutrition Education-Based Cooking Workshops in Community-Dwelling Adults Aged 50 Years and Older." Journal of Nutrition in Gerontology and Geriatrics 2015, 34 (4): 369-387.

16-Flego, A., et al: "Jamie's Ministry of Food: Quasi-Experimental Evaluation of Immediate and Sustained Impacts of a Cooking Skills Program in Australia." PLoS One 2014, 9 (12).

17-Wrieden, W. L., Anderson, A.S., Longbottom, P.J., Valentine, K., Stead, M., Caraher, M., Lang, T., Gray, B. and Dowler, E: "'The impact of a community-based food skills intervention on cooking confidence, food preparation methods and dietary choices - an exploratory trial'." Public Health Nutrition 2007, 10 (2): 203-211. 